\title{
THE EVALUATION OF A DIVERSITY PROGRAM
}

\author{
CHRISTA FOUCHE \\ School of Social and Cultural Studies \\ Massey University, Auckland \\ CHERYLENE DE JAGER \\ ANNE CRAFFORD \\ Department of Human Resource Management \\ Rand Afrikaans University
}

\begin{abstract}
This article reports on the evaluation of a programme that was designed and developed in an attempt to address the reasons why diversity programmes fail. A large company in the banking sector initiated the development of the product and keynote personnel from this company evaluated the content. The content was found to adhere to Best Practice requirements.
\end{abstract}

\section{OPSOMMING}

Die artikel evalueer die inhoud van 'n diversiteits-program wat ontwerp en ontwikkel is ten einde die redes waarom diversiteits-opleiding faal, aan te spreek.' $n$ Groot maatskappy in die banksektor het die ontwikkeling geinisieer en 'n aantal senior personeellede is genader om die inhoud te evalueer. Daar is bevind dat die inhoud aan wêreldklas standaarde voldoen.

One of the most important implications of globalisation is that workers from different racial, cultural and ethnic backgrounds, as well as workers with different sexual orientations and people with disabilities - enter the workplace with increased strength, both in numbers and in feelings of self-worth. They demand that their realities be given credibility, their needs be addressed and that their approaches be added to the pool of acceptable alternatives (Nieuwmeijer, 2001).

Diversity brings stimulation, challenge and energy; it does not always lead to harmony. The mix of cultures, genders, life-styles and values often become a source of misunderstanding and conflict. Many enlightened managers, from senior company directors to shop-floor supervisors, want to create business environments where differences are valued and where people, who look, talk and think differently can work productively together (Nieuwmeijer, 2001)

Nieuwmeijer (2001) states that the task is daunting, especially in South Africa with its history of apartheid, discriminatory labour practices and freedom-struggles - first political and now socioeconomical, with emotions and pressure of equal opportunities and affirmative action influencing diversity in the workplace. People of all races who still live in the past are unable or unwilling to make a quantum jump into the future in order to become competitive. She states that in order to create a role model for diversity management in the South African business environment, it is necessary to understand the concepts "global competitiveness" and "world-class business practices". The underlying reason for this is that the diversity function provides the innovative and competitive edge of the business organisation's journey in pursuit of world-class. Leadership simply cannot treat a culturally diverse workforce as a homogeneous group. (Human, 1996a, Manning, 1997a, Booysen, 1999) While the resistance, resentment and aggression shown towards management by a certain faction of workers must be taken into account, the fears and uncertainties of others must be considered (Human, 1996, Manning, 1997).

In an attempt to change the existing mental model that diversity is a result of affirmative action, a broader definition of diversity against a global perspective is introduced. The definition provides a focus away from the current race and gender issue. In order to manage diversity effectively in organisations it is important to understand the meaning and implications of the

Requests for copies should be addressed to: C De Jager, Department of Human

Resource Management, RAU, PO Box 524, Auckland Park, 2006 concept "diversity". Concept classification includes gender and race, although diversity does not automatically mean "with respect to gender and race". O'Mara (1994) defines diversity as "Race, gender, age, language, physical characteristics, disability, sexual orientation, economic status, parental status, education, geographic origin, profession, lifestyle, religion, position in the company hierarchy, and any other difference" (p. 115).

Affirmative action, included in the Labour Relations Act 66 of 1995, the Employment Equity Act 55 of 1998 and the Promotion of Equality and Prevention of Unfair Discrimination Act 4 of 2000, is direct in its intentions to promote workplace democracy - yet surveys and corroborated opinions are aligned in concluding that business in South Africa on the whole is lagging behind in effecting change leading towards becoming 'world class' (Nieuwmeijer, 2001).

Booysen (1999) reiterates that more people of previously disadvantaged groups are entering both the market place and managerial ranks. The survival of organisations depends on the effective management of this diversity. Discovering unity through diversity by understanding the strengths and weaknesses of different individuals are essential to reaching the organisation's potential. Human (1991; 1996a; 1996b), and Grobler (1996) point out that if a workforce is diverse, cultural diversity needs to be managed specifically in order for organisations to function optimally. Managing diversity requires the creation of an open, supportive, and responsive organisation in which differences are valued, encouraged, and managed.

Rhinesmith (1996, p. 9) however, points out that the first important challenge in diversity management is the compilation of effective strategies and structures, which are necessary for quick decision-making and the best competitive advantage. He is of the opinion that no global strategy can be achieved without translation into the policies, structures, processes and procedures of the company. This implies that the integration of these elements into an effective system is the foundation of a global strategy. Successful integration however is dependent on the nature and quality of organisational leadership.

Willard Rappleye (March 2001) states that diversity in the workplace has "reached the top level of integration in strategy, practice and policy at a handful of major corporations where it is understood to be the great new opportunity for competitive advantage" (www.corporateleadershipcouncil.com). 
It is clear and evident that diverse workplaces are the result of a number of factors, namely: globalisation, legislation and the entrance of previously disadvantaged groups into the workplace. Managers were equipped to manage sameness, and the shift towards managing a diverse workforce requires new knowledge and skills sets.

\section{BACKGROUND TO THE PROBLEM}

A large number of organisations provide programmes in an attempt to equip managers with the skills to manage diversity. The workshop presented at the company in the banking sector succeeded in creating awareness about diversity to some extent, but made no significant contribution towards equipping managers with the necessary skills to manage diversity. A programme, with the relevant content that will provide managers with the skills and information to manage a diverse work force, was needed.

\section{The process}

The first step was to assess the current product content and process:

- The process commenced with a fact-finding exercise.

- Informal interviews and general discussions were used to gather the information.

- There were two programmes available and the facilitators could choose which programme to use. This resulted in uncertainty.

- Some facilitators tried to combine the two programmes and it was evident that there was no clear process or guidelines.

- The designer of the current delegate handout was interviewed and the philosophy behind the choice of content included in the workbook was explained.

- The accompanying facilitator's guide was assessed.

- The diversity custodian was interviewed several times to determine the purpose, the envisioned outcomes and the preferred perspective of the workshop.

- It was evident that the intended outcomes were not realised by the programme content and process.

- The operating facilitators were interviewed, either face-toface, telephonically or by means of an e-mail, in order to determine and evaluate the effectiveness and the applicability of the current programme content and process.

- Some strategic People Management specialists were interviewed.

- The existing programme material and the implementation process were evaluated against the purpose and the outcomes the custodian hoped to achieve.

- The existing process was assessed and commented on.

- The match between the programme content, the process followed and the training methodology used, was assessed.

- A training workshop was attended and evaluated.

- Recommendations were presented to an opinion team. The team represented all the parties previously interviewed.

- Content and process adjustments were discussed in a brainstorming session.

- The team decided that some of the current programme content must remain but that a new programme or programmes and processes had to be designed.

- It was agreed that the programme should include: userfriendly delegate guides, facilitator guides or toolkit/programmes that cater for a variety of facilitation styles and content that adheres to Best Practice requirements.

The second step was to decide what was needed:

- More than one programme was needed in order to cater for the different target groups.

- There are no unit standards available for diversity training and a standard generating body was formed only recently.

- A literature search indicated that there are merely guidelines for successful and unsuccessful diversity training.
- No Best Practice requirements are currently available.

- The guidelines for what constitutes successful or unsuccessful diversity training were used as the basis for the literature review and were used as Best Practice guidelines.

- The literature review provided guidelines for the programme content as well as for a possible process that can be followed to ensure success.

- These guidelines formed the basis of the content of the programme.

The third step was to list the reasons why diversity programmes fail and to account for these reasons by conducting literature research. The top reasons why diversity training fails will now be listed and discussed against a literature review (http://www.diversitydtg.com/articles/topten.html).

1. Diversity training is driven from the Affirmative Action or Employment Equity Office. Diversity training must come from the whole organisation through a steering committee made up of employees from a representative cross-section of the organisation.

Managing diversity is not something that one puts in a onemonth action plan with the expectation of concluding it three months later. Managing diversity is a long-term change process involving various stages, each with particular characteristics and problems, all of which are affected by the organisation's culture and resources. It is thus clear that a diversity advisory or steering committee has to be established (http://www.diversitydtg. com/articles/bestprac.html) and that diversity training is the responsibility of the whole organisation.

2. Diversity training is done because it is the right or moral thing to do: make the business case for diversity training first.

Cox (1994) states that the types of organisational change facilitated by diversity are (1) moral, ethical and social responsibility goals, (2) legal obligations and (3) economic performance goals. It is therefore of extreme importance that the business case is argued and that one should avoid moral justifications for diversity programmes. It is thus clear that one should stay away from moral justifications and base diversity programmes on business reasoning (www.corporateleadershipcouncil.com and http://www.diversitydtg.com/articles/ bestprac.html). Training is all the organisation is doing. The organisation is not reviewing or scrutinising hiring, promotion, leadership development and business practices.

Human (1991; 1996a; 1996b) and Grobler (1996) point out that if a workforce is diverse, cultural diversity needs to be managed specifically in order for organisations to function optimally. Managing diversity requires the creation of an open, supportive, and responsive organisation in which differences are valued, encouraged, and managed. O'Mara (1994) argues that defining managing diversity as a process highlights its evolutionary nature. It allows corporations to develop (evolve) steps for generating a natural capability to tap the potential of all employees.

The recruitment and selection strategy should attempt to diversify the recruiting pool without compromising standards (http://www.diversitydtg.com/articles/bestprac.html). Susan Jackson (http://inform.umd.edu./Diversity/Response/ Workplace/.io.htmll) supports this statement by stating that advice on how to design and conduct fair and unbiased selection interviews and performance appraisals, that will enable and support workforce diversity, is needed.

3. Diversity training has management support, but not its commitment. The organisation will wait for the fad to pass if management does not participate and provide real evidence of its commitment to the process. 
Carlton (2000) states that when diversity is fuelled and encouraged by a liberating leader(s)-led environment, its goal is always ever increasing and sustained performance. He continues that unless top management commits time and constructs tangible diversity targets for which it is held accountable, little will change.

Grobler (1996) points out that the future leaders of companies in South Africa should reflect on the demographic composition of the country. The leadership philosophy should be aimed at the future and achievement based on partnership. He continues that the days of autocratic leadership have passed - the concepts of demand and control are simply no longer acceptable. Leadership must include elements such as integrity, fairness, democracy, empowerment, broad consultation, and respect for the individual and sensitivity for cultural diversity. Grobler (1996) concludes by saying "the future leader must also be caring, show empathy, be willing to serve, and recognise human worth" (p. 11).

4. The training being conducted is off the shelf and not custom designed to meet the unique need of a specific organisation or business unit.

Tafoya (2002) states that a Diversity Program effort is a longterm change effort because of the focus on assessing systems, policies and practices of an organisation and making them more relevant to the diverse needs of the employees and customer or client. This implies that training programmes have to be customised to meet the unique need of a specific organisation.

5. Training is being developed and led solely by external diversity consultants and trainers.

No ownership or buy-in is solicited and the programme eventually perishes and the external diversity trainer is the "fall guy".

6. Diversity training was designed and developed without a formal needs analysis or diagnosis of the organisation. What did the designer know anyway?

Tafoya (2002) states that an audit or assessment or survey has to be completed to identify the organisation's diversity issues and to gauge organisational culture. This involves a review of the organisation's systems, plans, and policies to guide, reward, and sanction behaviour to diagnose existing conditions. He concludes by stating that the latter is necessary for planning training and other diversity activities to address relevant diversity issues.

7. The diversity-training programme is awareness-based but provides no skills, no practical, "hands-on", everyday tools.

Nieuwmeijer (2001) states that in most traditional business organisations the knowledge and skills to manage diversity are normally not part of the managers' experience and adds that whilst old methods do not suffice, new ones have yet to be developed. Jamieson and O'Mara (1991) developed a flexmanagement model that can provide managers with the necessary flexibility for managing the changing workforce. This model is a good benchmark to use for developing new diversity management models.

South African managers need to extract the best management tools from schools representing a variety of cultural management orientations within and outside of South Africa. They need to understand and value the cultural diversity of the South African workforce and to be flexible in using "what works" from a cultural perspective. Only then will South African organisations gain the competitive edge (Nieuwmeijer, 2001). Jamieson and O'Mara (1991) provide guidelines on how to develop skills for managing a diverse workforce. Flexibility is an important factor in determining success in managing the changing workforce.

8. The diversity training had no formal follow-up. Action items had no owners and nobody revisited the training. Organisations need to have internally driven initiatives supported by senior management's commitment as well as by ongoing awareness campaigns.

Organizations should acknowledge and celebrate diversity within the employment ranks before attempting to value and manage diversity (http://www.diversitydtg.com/articles/ bestprac.html). Organizations should also celebrate and share diversity training success stories (http://www. diversitydtg. com/articles/bestprac.html). It is thus clear that the diversitytraining programme should form part of a larger intervention as well as be part of an ongoing and integrated process.

9. Diversity programmes should not occur in a vacuum and must be supported by other initiatives and activities. Diversity training programmes are not the cure all, and all employees should be encouraged to initiate and participate in potential diversity initiatives.

Jamieson and O'Mara (1991) highlight the importance of taking a systematic approach to planning for and managing the kinds of changes required by the new, more diverse workforce. This involves developing policies, systems, and practices to accommodate a changing workforce. The FLEX-MANAGEMENT model can provide a roadmap that will help organizations and managers to think and act differently about modifying procedures at individual and organizational levels.

The fourth step was to list the reasons why diversity-training programmes succeed.

Successful diversity training (http://www.diversitydtg.com/ articles/topten.html):

1. is developed through a partnership of internal employees (diversity steering committee) and an external subject matter expert (diversity consultant and trainer).

2. has a senior-level advocate or champion.

3 . is supported by sound research. The organisation is presenting the business rationale and the bottom-line results of doing this work. The organisation also presents the cost of not doing this work because their future, market share, retention of talent and performance depend on understanding and anticipating the needs of an increasingly diverse workplace and marketplace.

4. occurs in a supportive corporate culture, one that reflects an ongoing commitment to continuous learning.

5. is "skill-based": all diversity training is awareness based; you need to develop a set of skills or a diversity toolkit.

6. ensures transfer of skills from the training room to the workplace: diversity training should educate and empower all employees with new skills and tools.

7. is not dependent on one person (diversity trainer or manager) to save the organisation. Steering committees representing the whole organisation must champion the initiatives.

8. does not occur in a vacuum and must be supported by other initiatives and activities: training alone is not the cure all. All employees should be encouraged to initiate and participate in potential diversity initiatives.

9. takes on a life of its own: employees are encouraged to get involved and to develop and lead discussions. Mini-training and other activities should foster an ongoing and continuous commitment to creating and promoting a more inclusive work environment that values our differences.

It is thus evident that there is a strong relationship between the reasons for the success and failure of diversity-training 
programs. The evaluation questionnaire that was used to evaluate the content of the diversity programme has taken both sets of guidelines into consideration.

The final step was then to design a programme.

- A programme and process toolkit was designed.

- The content of this diversity management programme needs to be evaluated in order to determine whether it addressed all the requirements of a Best Practice product. This is the focus of the research undertaken.

Tayeb (1998) quotes a Dutch manager who expresses this point well.

"Sometimes when I hear my company talk about harmonisation, I think they want us all to play the same note. Well, I am a musician, and let me tell you harmony doesn't mean that; it means that we all play different notes, but together we sound beautiful (p. 180)."

The original programme, "Valuing Diversity", is mainly awareness based. A programme with the relevant content that will assist the managers in how to manage diversity is included in the process and is called: "Harmonising Diversity."

The above-mentioned literature overview has led to the development of the product that now needs to be evaluated. It has to be taken into consideration that a change management component, a training component, as well as an integrated approach with the existing interventions in the organisation, influenced the design and content selection process.

\section{Project Goals}

The aim of the research was to 1) compare the content of a diversity management programme to Best Practice requirements; and 2) to make conclusions regarding the further development of a diversity programme with the relevant content, in an attempt to create a Best Practice product.

\section{RESEARCH METHODOLOGY}

\section{Participants/respondents}

Convenience sampling as described by Kerlinger (1986) was used. Rossi and Freeman (1989) support the use of convenience sampling and adds that formative evaluation may include testing and assessing a programme at one or a few sites, or with a small sample of targets, prior to full implementation.

The target boundaries (adequate target specification establishes boundaries, that is, rules determining who or what is included and excluded when the specifications are applied) were determined by the "as-is" situation (Rossi \& Freeman, 1989).

De Vos, Strydom, Fouche and Delport (2002) state that the use of key informants means that a few people known to be involved with the services needed of the client group are asked for their opinions. Only a selected number of participants was involved in the evaluation process. The population was defined as thirty-five (35) highly qualified professionals, specialists, managers and senior managers, with years of training and organisational development experience involved with the diversity training programme. Thirty-five questionnaires were distributed to the whole population and thirty-one questionnaires were returned. The participants had to evaluate the content after reviewing the programme toolkit.

Of the 31 participants, $10(32,3 \%)$ were male and $21(67,7 \%)$ were female. Their mean age was 36.7 years. The majority of these participants are managers, professionals, senior managers and specialists. Of the 31, one participant has a PhD, $9(29,0 \%)$ have master's degrees and $12(38,7 \%)$ have honours degrees. Only two participants have only grade 12 , three have a diploma and the remaining four have a first degree. It is indeed a very exclusive and selective group that was used to evaluate the content. These participants have years of experience in the training and organisational development field.

\section{Measuring instrument}

A questionnaire was distributed electronically and by hand. This questionnaire was developed using the guidelines for Best Practice. As such, the following elements were included as items in the questionnaire (i.e. the extent to which the respondents regarded the following as part of the programme):

- The economic rationale for implementing Employment Equity (the business case for diversity training).

- The information to establish an Employment Equity forum (Employment Equity act and the implications thereof).

- The guidelines to establish an Employment Equity forum (how to establish a forum in order to comply to legislative requirements)

- Guidelines to assist in the adjustment of existing policies and procedures in the company to support the Employment Equity drive (the diversity-training programme forms an integral part in order to enable the Employment Equity drive)

- The commitment of top management for the diversitytraining programme

- Top management's commitment to the process

- The nature of the programme as being customised and meeting the unique needs of the organisation

- The input from various key role-players

- Assistance to management to construct tangible diversity targets for which it is held responsible

- A proper and comprehensive needs analysis

- Guidelines to skills needed to manage diversity.

- Programme content inclusive of practical, "hands-on" everyday tools

- The line of thought that the diversity-training programme is merely an aspect of the complete diversity drive in the organisation

- The programme link to the other interventions that are currently running in the company

- Guidelines on how to create a forum to communicate diversity success stories.

- Guidelines to design and develop action plans for activities that will assist in creating an inclusive workforce.

Royse (1992) states that developing a good questionnaire requires that one constantly has to revise the instrument in order to make sure that a good instrument has been constructed. The questionnaire has been adjusted several times in order to ensure that it is set out to evaluate what needs to be evaluated.

\section{Procedure}

De Vos et al (2002) state that the issue of evaluation is not whether a programme should be evaluated, but rather how it will be evaluated. A systematic approach to evaluation as researched by Rossi and Freeman will be used to evaluate whether or not the programme content addresses the reasons why diversity training programmes fail. The aim is to improve the content of the existing programme and is therefore known as formative evaluation (De Vos et al., 2002). Programme monitoring is, in essence, a type of formative evaluation (De Vos et al., 2002).

An evaluability assessment is a form of qualitative research that permits the evaluator to develop an understanding of the program and to enlist support for subsequent evaluation activities. (Rossi \& Freeman, 1989) The above guidelines were used during the process followed in order to assess the 'as-is' situation.

Rossi and Freeman (1989) define evaluation research as follows: "Evaluation research is the systematic application of social research procedures for assessing the conceptualisation, design, 
implementation, and the utility of social intervention programs (p. 18)." They continue by stating that evaluation research is a robust arena of activity directed at collecting, analysing and interpreting information on the need for, implementation of, and effectiveness and efficiency of intervention efforts to better the lot of humankind. Royce (1992) states that programme evaluation is like basic research in that both follow a logical, orderly sequence of events. Evaluations are undertaken for a variety of reasons: to judge the worth of ongoing programs and to estimate the usefulness of attempts to improve them; to assess the utility of innovative programs and initiatives; to increase the effectiveness of program management and administration; and to satisfy the accountability requirements of program sponsors (Rossi \& Freeman, 1989).

Evaluations focus on the extent and severity of the problems regarding the intervention and then design the programs in such a way in order to ameliorate them. In the conduct of ongoing and new programs, evaluation helps to determine the degree to which the programs are effective - that is, how successfully they are reaching the intended target populations and are providing the resources, services, and benefits envisioned by their sponsors and designers (Rossi \& Freeman, 1989). De Vos et al (2002) state that the more reliable the instruments and observations, the more reliable the results. Rossi and Freeman (1989) continue by stating that for accountability purposes, and to aid in decisions concerning whether programs should be continued, expanded or curtailed, evaluation should consider costs in relation to benefits and compare an intervention's cost effectiveness with that of alternative strategies for allocating scarce resources. Rossi and Freeman (1989) concludes this statement by stating that evaluation should provide the most valid and reliable findings possible within political and ethical constraints and the limitations imposed by time, money and human resources. In the design of the evaluation questionnaire, two key concepts were taken into consideration.

\section{The following concepts were of importance for the} evaluation in question:

Intervention:

Any program or other planned effort designed to produce changes in a target population (Rossi \& Freeman, 1989). For the purpose of this research, the term intervention referred to the designed diversity management programme as implemented in a company in the banking sector.

\section{Target population:}

The persons, organisation, communities or other units at which an intervention is directed (Rossi \& Freeman, 1989). For the purpose of this research the members of the target population can be regarded as the keynote influencers in the company. They have the relevant qualifications, status and years of experience required to evaluate the content of the programme objectively.

The following statements are characteristics of evaluation research: (refer to Rossi \& Freeman, 1989)

- Its methods cover the gamut of prevailing research paradigms.

- A significant number of programmes were often hurriedly put into place, were poorly conceived, improperly implemented, and ineffectively administered.

- There is increased attention to fiscal accountability and the managerial effectiveness of programmes.

- There will continue to be resource restraints that require choosing which social or intervention areas to concentrate on and which social or interventions or programmes should be given priority.

- Intensive scrutiny of existing programmes will continue because of the pressure to curtail or dismantle those for which there is limited evidence of program efficiency and efficient delivery of services.
- Unanticipated problems with delivering the intervention or with the intervention itself may require modifying the programme, and consequently, the evaluation plan as well.

- The central purpose of evaluation differs from that of basic social research and evaluations fit into a different institutional and political context.

- The translation of logic into the procedure should depend upon context, purpose and expected payoff.

- The key goal is to design and implement an evaluation that is as objective as possible - that is, to provide a firm assessment, one that would be unchanged if the evaluation was replicated by the same evaluators or conducted by another group.

- The scope of the evaluation, the questions and the research procedures used depend on the purpose for which it is being conducted, e.g. a modification or expansion of an existing effort.

- Many programmes are not implemented and executed according to their original design.

- This evaluation will not focus on a cost-benefit or costeffectiveness analysis due to the fact that all possible resources needed to ensure the successful implementation of the intervention, have already been allocated and approved.

Rossi and Freeman (1989) state that new interventions are relatively rare and add that most programs introduced as "new and innovative" are modifications of existing practices. What makes an intervention innovative in our sense is that the particular treatment has never been applied to the population specified. According to them, a programme is innovative if it has not been subject to implementation and assessment in the following way: the intervention itself is still in an emerging or research and development ("R\&D") phase - that is, there is no (or very limited) evidence that it has an impact as an installed program. De Vos et al. (2002) state that what really distinguishes intervention research from programme evaluation is the fact that when intervention research is attempted, something new is created and then evaluated. They continue by saying that when one is asked to evaluate an existing programme, one is doing programme evaluation.

The existing program needed to be fine-tuned. Program fine-tuning typically occurs because program sponsors and staff are dissatisfied with the effectiveness or the efficiency of their interventions, or both (Rossi \& Freeman, 1989). Rossi and Freeman (1989) state that fine-tuning basically requires three related sets of activities on the part of the sponsors, program staff, and evaluators: reappraising program objectives and outcomes, undertaking reputability assessments, and re-planning/re-designing the program. De Vos et al., (2002) list six steps for the process of evaluation. These six steps are: 1) needs assessment, 2) evaluability assessment, 3) programme monitoring, 4) impact assessment, 5) cost-effectiveness evaluation and 6) utilisation evaluation.

Rossi and Freeman (1989) state that every evaluation must be tailored to its program and add that the role evaluation can play varies according to whether the program is a new one being designed and implemented or an established program to be evaluated or fine-tuned. Existing programs are more difficult to evaluate in terms of their impact and efficiency but evaluation can help to ensure that the program is implemented correctly and can facilitate planning or program improvement. Royse (1992) states that when there is a perception that a programme could be improved - that it could become better in some way, then it needs to be evaluated. A considerable number of evaluations are directed at fine-tuning of programs, for example, modifying the program to increase its effectiveness (Rossi \& Freeman, 1989).

Reputability assessments are evaluations based on the clients' opinions of the program procedures and services (Rossi \& Freeman, 1989). The latter will be evaluated by 
means of a questionnaire. Rossi and Freeman (1989) state that formative studies are evaluations that assess the conduct of programmes during their early stages. Royse (1992) supports Rossi and Freeman and adds that formative evaluation is employed to adjust and enhance a programme and serves to guide and direct programmes - especially new programmes. The re-designed diversity management programme content has just been designed, developed and distributed for evaluation.

\section{RESULTS}

The data from the questionnaire was analysed by utilising SPSS 11.01 for windows.

Descriptive statistics were calculated. The results are reported in terms of whether or not the content of the programme addresses the reasons why diversity programmes fail or succeed.

\section{TABle 1}

FREQUENCIES OF REACTION TO QUESTIONNAIRE ITEM

\begin{tabular}{|c|c|c|c|c|c|c|}
\hline $\begin{array}{l}\text { St } \\
\text { di }\end{array}$ & $\begin{array}{l}1 \\
\text { Strongly } \\
\text { disagree }\end{array}$ & 2 & 3 & 4 & $\begin{array}{l}5 \\
\text { strongly } \\
\text { agree }\end{array}$ & $\mathbf{N}$ \\
\hline $\begin{array}{l}\text { 1. Economic rationale for } \\
\text { implementing Employment } \\
\text { Equity }\end{array}$ & 0 & 0 & 4 & 20 & 7 & 31 \\
\hline $\begin{array}{l}\text { 2. Information to establish an } \\
\text { mployment Equity forum }\end{array}$ & 0 & 4 & 4 & 15 & 8 & 31 \\
\hline $\begin{array}{l}\text { 3. Guidelines to establish an } \\
\text { Employment Equity forum }\end{array}$ & 0 & 3 & 7 & 12 & 9 & 31 \\
\hline $\begin{array}{l}\text { 4. Information to adjust policies } \\
\text { and procedures to support } \\
\text { Employment Equity drive }\end{array}$ & 0 & 7 & 9 & 12 & 3 & 31 \\
\hline $\begin{array}{l}\text { 5. Commitment and support of } \\
\text { top management for the } \\
\text { program }\end{array}$ & 0 & 4 & 14 & 10 & 2 & 30 * \\
\hline $\begin{array}{l}\text { 6. Evidence of top management's } \\
\text { commitment to the process }\end{array}$ & 0 & 10 & 13 & 5 & 3 & 31 \\
\hline $\begin{array}{l}\text { 7. Customizes product meeting } \\
\text { the unique needs of the } \\
\text { organisation }\end{array}$ & 0 & 0 & 14 & 15 & 2 & 31 \\
\hline $\begin{array}{l}\text { 8. Input from various key } \\
\text { role-players }\end{array}$ & 1 & 1 & 7 & 2 & 10 & 31 \\
\hline $\begin{array}{l}\text { 9. Assistance to conduct tangible } \\
\text { diversity targets }\end{array}$ & 0 & 5 & 5 & 19 & 2 & 31 \\
\hline $\begin{array}{l}\text { 10. Displays comprehensive needs } \\
\text { analysis }\end{array}$ & 0 & 1 & 11 & 14 & 5 & 31 \\
\hline $\begin{array}{l}\text { 11. Guidelines of skills to be } \\
\text { developed to manage diversity }\end{array}$ & 0 & 1 & 9 & 16 & 5 & 31 \\
\hline $\begin{array}{l}\text { 12. Provide manager with practical, } \\
\text { "hands-on" everyday tools }\end{array}$ & 1,0 & 5 & 5 & 19 & 2 & 31 \\
\hline $\begin{array}{l}\text { 13. The program is an aspect of } \\
\text { the diversity drive in the } \\
\text { organisation }\end{array}$ & 0 & 3 & 11 & 10 & 7 & 31 \\
\hline $\begin{array}{l}\text { 14. Link to the other interventions } \\
\text { that are currently running }\end{array}$ & s 0 & 4 & 6 & 16 & 5 & 31 \\
\hline $\begin{array}{l}\text { 15. Provide to create a forum to } \\
\text { communicate diversity success } \\
\text { stories }\end{array}$ & 0 & 3 & 11 & 15 & 2 & 31 \\
\hline $\begin{array}{l}\text { 16. Promote the design and } \\
\text { development of an action plan }\end{array}$ & 0 & 4 & 8 & 12 & 7 & 31 \\
\hline
\end{tabular}

*Not all items were completed

\section{As can be seen form Table 1:}

Question 1:

Of the 31 participants, $4(12,9 \%)$ were uncertain, $20(64,5 \%)$ agreed and $7(22,6 \%)$ strongly agreed that the content contained a strong argument and convinced them of the economic rationale for Employment Equity.
Question 2:

Of the 31 participants, $4(12,9 \%)$ disagreed, $4(12,9 \%)$ were uncertain, $15(48,4 \%)$ agree and $8(25,8 \%)$ strongly agreed that the content provides one with the necessary information to enable one to establish an Employment Equity forum.

\section{Question 3:}

Of the 31 participants, $3(9,7 \%)$ disagreed, $7(22,6 \%)$ were uncertain, $12(38,7 \%)$ agree and $9(25,8 \%)$ strongly agreed that the content provides the necessary guidelines to enable one to establish an Employment Equity forum.

\section{Question 4:}

Of the 31 participants, $7(22,6 \%)$ disagreed, $9(29,0 \%)$ were uncertain, $12(38,7 \%)$ agreed and $9(29,0 \%)$ strongly agreed that the content assists you in determining how to adjust the existing policies and procedures in the organisation to support the Employment Equity drive in your business plan.

Question 5:

Of the 31 participants, $4(13,3 \%)$ disagreed, $14(46,7 \%)$ were uncertain, $10(33,3 \%)$ agreed and $2(9,7 \%)$ strongly agreed that the content reflects the commitment and support of top management for the diversity-training programme.

Question 6:

Of the 31 participants, $10(32,3 \%)$ disagreed, 13 (41,9\%) were uncertain, $5(16,1 \%)$ agree and $3(9,7 \%)$ strongly agreed that the content provides real evidence of top management's commitment to the process.

\section{Question 7:}

Of the 31 participants, $14(45,2 \%)$ were uncertain, $15(48,4 \%)$ agreed and $2(6,5 \%)$ strongly agreed that the content reflects a customised product meeting the unique needs of the organisation.

\section{Question 8:}

Of the 31 participants, 1 (3.2\%) strongly disagreed, $1(3,2 \%)$ disagreed, $7(22,6 \%)$ were uncertain, $12(38,7 \%)$ agreed and 10 $(32,3 \%)$ strongly agreed that the content indicates that the design of the product solicited the input from various key roleplayers.

\section{Question 9:}

Of the 31 participants, $5(16,1 \%)$ disagreed, $5(16,1 \%)$ were uncertain, $19(61,3 \%)$ agree and $2(6,5 \%)$ strongly agreed that the content assists management to construct tangible diversity targets for which they are held accountable.

\section{Question 10:}

Of the $31,1(3,2 \%)$ disagreed, $11(35,5 \%)$ were uncertain, 14 $(45,2 \%)$ agreed and $5(16,1 \%)$ strongly agreed that the content displays that a proper and comprehensive needs analysis was conducted.

\section{Question 11:}

Of the 31 participants, $1(3,2 \%)$ disagreed, $9(29,0 \%)$ were uncertain, $16(51,6 \%)$ agreed and $5(16,1 \%)$ strongly agreed that the content provides guidelines as to which set of skills needs to be developed in order to be able to manage diversity.

\section{Question 12:}

Of the 31 participants, $5(16,1 \%)$ disagreed, $5(16,1 \%)$ were uncertain, $19(61,3 \%)$ agreed and $2(6,5 \%)$ strongly agreed that the content provides the managers with practical, "hands-on" every day tools.

\section{Question 13:}

Of the 31 participants, $3(9,7 \%)$ disagreed, $11(35,5 \%)$ were uncertain, $10(32,3 \%)$ agreed and $7(22,6 \%)$ strongly agreed that the content imposes the line of thought that the diversity training programme is merely an aspect of the complete diversity drive in an organisation. 
Question 14:

Of the 31 participants, $4(12,9 \%)$ disagreed, $6(19,4 \%)$ were uncertain, $16(51,6 \%)$ agreed and $5(22,6 \%)$ strongly agreed that the content is linked to the other interventions that are currently running in the organisation.

\section{Question 15:}

Of the 31 participants, $3(9,7 \%)$ disagreed, $11(35,5 \%)$ were uncertain, $15(48,4 \%)$ agreed and $2(6,5 \%)$ strongly agreed that the content provides guidelines as to how to create a forum to communicate diversity success stories.

\section{Question 16:}

Of the 31 participants, $4(12,9 \%)$ disagreed, $8(25,8 \%)$ were uncertain, $12(38,7 \%)$ agreed and $7(22,6 \%)$ strongly agreed that the content promotes the design and development of an action plan for activities that will assist in creating an inclusive workforce.

It is clear from the data reflected in table 1 that the key informants agreed or strongly agreed with the following aspects of the programme:

- The programme content addresses the economic rationale for implementing Employment Equity and the business case for diversity training.

- The information in the programme content enables one to establish an Employment Equity forum.

- The programme content provides guidelines to enable one to establish an Employment Equity forum.

- The programme content provides guidelines to assist one on how to adjust the existing policies and procedures in the company to support the Employment Equity drive in one's business plan.

- The programme content reflects that the design of the programme solicits the input form various key role-players.

- The programme content assists management to construct tangible diversity targets for which they are held responsible.

- The programme content displays that a proper and comprehensive needs analysis was conducted.

- The programme content provide guidelines to assist one as to what set of skills needs to be developed in order to be able to manage diversity.

- The programme content provides the managers with practical, "hands-on" everyday tools.

- The programme content imposes the line of thought that the diversity-training programme is merely an aspect of the complete diversity drive in an organisation.

- The programme content indicates that the programme is linked to the other interventions that are currently running in the company.

- The programme content provides guidelines as to how to create a forum to communicate diversity success stories.

- The programme content provides guidelines to design and develop action plans for activities that will assist in creating an inclusive workforce.

It was further clear that the evaluators disagreed or were uncertain with the following elements:

- The programme content reflects the commitment of top management for the diversity-training programme.

- The programme content provides real evidence of top management's commitment to the process.

- The programme content reflects a customised programme that meets the unique needs of the organisation.

\section{DISCUSSION}

The results reveal that the programme content reflects the economic rationale for Employment Equity as well as a business case for diversity programmes. The programme content contains the necessary information as well as the guidelines to enable one to establish an Employment Equity forum.
There is a slight uncertainty regarding the fact that the content provides sufficient guidelines as to how to adjust the existing policies and procedures in the company to support the Employment Equity drive in the different business units. The content needs to be revised and a project team will assist in designing a template in order to assist the project managers to adjust the policies and procedures in the company to align with the Employment Equity requirements, as well as with the strategies of the business units.

The results reflect that the design of the product solicited the input from various key role-players and that it assists management to construct tangible diversity targets for which they are held accountable. The content also displays that a proper and comprehensive needs analysis was conducted and that the content includes guidelines as to which set of skills needs to be developed in order to be able to manage diversity.

The results indicated that the content provides the managers with practical, "hands-on" everyday tools that can assist them in managing a diverse workforce. The content provides comprehensive details about the flex-management model. The content also links the diversity training programmes to the other interventions that are currently running in the company. The results also reflect that guidelines on how to create a forum where the business unit can communicate diversity success stories are included in the content.

The results, however, reflect some areas of concern. The participants' response indicated that the content does not reflect the commitment and support of top management for the diversity-training programme. The response also indicated that the content does not provide real evidence of top management's commitment to the process. The content will be adjusted and a process will be designed to solicit the buy-in and support of top management. It is suggested that a template, which contains a guideline with an agreement of intent is to be included in the content. The diversity intervention in a business unit should reach beyond the fact that the diversitytraining programme was attended. Processes need to be designed to transfer the skills and knowledge gained at the training session to the workplace.

One of the reasons why diversity programs fail is due to the fact that one first has to create an awareness of the diversity issues before one can value or manage diversity. The content of the diversity- training programme will include a number of suggestions on how to design diversity awareness campaigns in a business unit.

The results also indicated that the content does not reflect the fact that it was customized to meet the unique needs of the organisation. The content of the diversity-training programme is available in hardcopy as well as in an electronic format. Templates provide guidelines on how to adjust the content to comply with the strategies of the different business units. A training process needs to be designed to assist the users of the content to fully utilise the potential of the content.

The results also indicate that the content does not impose the line of thought that the diversity training-programme is merely an aspect of the complete diversity drive in the organisation. The company has launched a number of initiatives in an attempt to rectify the latter statement. The topic of diversity training and diversity management has been included in most of the content of other initiatives in the organisation.

The results indicate some uncertainty whether the content promotes the design and development of an action plan for activities that will assist in creating an inclusive workforce. The content does in fact contain a template that attempts to provide guidelines for the user on how to 
create an action plan. The content needs to now include a list of activities to provide the users with guidelines on how to design and develop activities and initiatives for creating an inclusive workforce.

The results have been obtained by using convenience sampling. The next step will now be to fine-tune the content, develop and design a facilitation process that will transfer the learning of the content, conduct a pilot training session and evaluate the content again.

Rossi and Freeman (1989) emphasize the above by stating that for any evaluation, many good designs can be proposed, but no perfect one. The content of the diversity-training programme is a living document and will be constantly evaluated and improved upon.

\section{REFERENCES}

Booysen, A.E. 1999. An examination of race and gender influences on the leadership attributes of South African managers: $D B L$ dissertation, University of South Africa, Pretoria.

Cox, T. (1999). Cultural Diversity in Organisations. San Francisco: Berrett-Koeler.

Charlton, G. (2000). Human Habits of Highly Effective Organisations. Western Cape: Van Schaik.

Cross, E.Y., Katz, J.H., Miller, F.A. \& Seashore, E. W. (1994). The Promise of Diversity. New York: Irwin.

De Vos, A. S., Strydom, H., Fouche, C.B. \& Delport, C.S.L. (2002). Research at Grass Roots. Pretoria: Van Schaik.

Grobler, P.A. (1996). Leadership Challenges Facing Companies in the New South Africa. Inaugural lecture, Department of Business Management, University of South Africa, Pretoria.

Human, L. (1991). 'Advancement, affirmative action and diversity: What South Africa can learn from the USA.' South African Journal of Labour Relations, August, 9 (12), 11-21.
Human, L. (1996a). Contemporary Conversations: Understanding and Managing Diversity in the Modern World. Coree, Senegal: Coree Institute.

Human, L. (1996b). Future competencies of managing diversity: What South African managers need. In M. E. Steyn \& K. B. Motshabi, Cultural Synergy in South Africa (pp. 171-184). Pretoria: Sigma.

Jamieson, D. \& O’Mara, J. (1991). Managing Workforce 2000. San Francisco: Jossey Bass.

Kerlinger, E.N. (1986), Foundations of behavioural research. New York: Rinehart \& Winston.

Manning, T. (1991). World-class strategies for winning your customers. Kenwyn: Juta.

Nieuwmeijer, L.J. (2001). Conflict and peace research: South African realities and challenges. Pretoria: HSRC.

O'Mara, J. (1994). Diversity Activities and Training Designs. San Diego: California Pfieffer.

Rhinesmith. S. H. (1996). A manager's guide to globalisation: Six skills for success in a changing world. Chicago: Irwin.

Rossi, P. H. \& Freeman. H.E. (1989). Evaluation: A Systematic Approach. London: Sage.

Royse, D. (1993). Program Evaluation: An Introduction. United States: Nelson-Hall.

Tayeb, M.H. (1996). The Management of Multicultural Workforce. New York: John Wiley.

Trends in diversity (March 2001). www.corporateleadership council.com

Tafoya, D. A. (12 March 2002). Guide for a model diversity plan. Retrieved April 9, 2002 from the World Wide Web: http://www.oaac.co.la.co.us/ModelDiversityPlan.html.

http://www.inform.umd.edu./Diversity/Response/Workplace/.ih. tml (4 October 2002).

University of Maryland, http://inform.umd.edu./Diversity/ Response/Workplace/.Io.htmll

A Report to the Carnegie Commission on Preventing Deadly Conflict. (July 1997). A house no longer divided: Progress and prospects for democratic peace in South Africa. 